\title{
Tool for the evaluation of cooperations for product development between SMEs
}

H. Kühnle, G. Wagenhaus

Fraunhofer Institute of Factory Operation and Automation

Sandtorst. 22

D-39106 Magdeburg, Germany

Tel: +49(0)391/4090-100,-102

e-mail: kuehnle@iff.fhg.de

\begin{abstract}
The need for description models for cooperations develops from the growing number of cooperation projects between SME. Starting from cooperation morphology, chances and risks of cooperations, the fundamentals of the management of cooperation processes are described. A conception for securing cooperation success that systematizes a wide range of experiences and thus allows a transfer to future cooperations is presented.
\end{abstract}

Keywords

Cooperation, cooperation management, enterprise combines

\section{INTRODUCTION}

More and more small and medium-sized enterprises have to pay in form of dramatic sales reductions for the effects of markets with ever increasing dynamics. As a reaction, these enterprises consequently remember their core competencies and reduce any efforts towards diversification. Another possible reaction, intercompany cooperation, frequently meets with reticence or rejection in these enterprises.

Today, cooperations are still characterized by a relatively long preparatory period, which is based on the fear of many top executives of losing laboriously developed 
core competencies. But especially cooperations for developing products and production are an efficient response to qualitatively novel demands on enterprises. At the end of the 80s, many large enterprises restructured their pyramid of suppliers and require of these small and medium-sized enterprises ever more complex services up to the point of actively participating in product development projects.

Besides organizational responses such as the introduction of new production conceptions (Kühnle, 1995), SME increasingly react to the difference between required and available response time with the establishment of cooperations, alliances, virtual networks, or enterprise combines.

Contrary to cooperations which are generally characterized by the spatial proximity of cooperation partners and good personal contacts between them, virtual enterprises or enterprise alliances do not rely on a physical contact of partners. They are rather involved in creating on principle the possibility of manufacturing products or supplying services without the need of their physical presence in foreseeable periods of time. Moreover, the virtual object is provided with an additional benefit which is to be tested with regard to client acceptance. (Schuh/Millarg/Görensen, 1998)

Especially in recent times, more alliances are formed and thus combine the performance of different enterprises. From the view of economy and particularly production sciences, this means that new manufacturing conceptions exceed narrow enterprise-specific bounds. On the other hand, these tendencies open up entirely new possibilities for policy and business promotion as cooperations, as a rule, tap markets for the respective alliance; in this way, canvassing new orders secures their existence or can ideally even create new jobs. Positive as well as negative experience gathered meanwhile from cooperation projects and combines forms the empirical basis for further scientific considerations and allows statements on the management of cooperation projects.

\section{COOPERATION MORPHOLOGY - A DESCRIPTION MODEL AS A BASIS OF DESIGN RECOMMENDATIONS}

Cooperations can be characterized with regard to the cooperation object, cooperation direction, to the type and intensity of exchange of goods and services as well as the time scale for joint work. Moreover, criteria such as company size, number and provenance of partners as well as the type of enterprise bonding can be ascertained (Fig. 1) 


\begin{tabular}{|c|c|c|c|c|c|c|}
\hline $\begin{array}{l}\text { Object of } \\
\text { cooperation }\end{array}$ & $\begin{array}{l}\text { procurement } \\
\text { purchase }\end{array}$ & productior & $\begin{array}{l}\text { soles } \\
\text { cistribution }\end{array}$ & $\begin{array}{l}\text { market } \\
\text { research }\end{array}$ & $\begin{array}{l}\text { research } \\
\text { development }\end{array}$ & others \\
\hline Cooperation orientation & \multicolumn{2}{|c|}{ horizontal } & \multicolumn{2}{|c|}{ vertical } & \multicolumn{2}{|c|}{ diagonal } \\
\hline Intensity & $\begin{array}{l}\text { exchange of } \\
\text { experience }\end{array}$ & \multicolumn{2}{|c|}{$\begin{array}{l}\text { coordination of lasks } \\
\text { and functions }\end{array}$} & $\begin{array}{l}\text { mutual } \\
\text { specialisatio }\end{array}$ & \multicolumn{2}{|c|}{$\begin{array}{l}\text { joint } \\
\text { venture }\end{array}$} \\
\hline Partner size & \multicolumn{3}{|c|}{ inhomogeneous } & \multicolumn{3}{|c|}{ homogeneous } \\
\hline Partner provenance & local & \multicolumn{2}{|c|}{ regional } & national & \multicolumn{2}{|c|}{ international } \\
\hline $\begin{array}{l}\text { Number of } \\
\text { enterprises }\end{array}$ & \multicolumn{2}{|c|}{$\begin{array}{l}\text { two-partner } \\
\text { cooperation }\end{array}$} & \multicolumn{2}{|c|}{$\begin{array}{l}\text { small-group } \\
\text { cooperation } \\
\text { 3-10 partners }\end{array}$} & \multicolumn{2}{|c|}{$\begin{array}{l}\text { large-group } \\
\text { cooperation }\end{array}$} \\
\hline $\begin{array}{l}\text { time } \\
\text { course }\end{array}$ & \multicolumn{2}{|c|}{$\begin{array}{l}\text { short-term } \\
\text { (less than } 5 \text { years) }\end{array}$} & \multicolumn{2}{|c|}{$\begin{array}{l}\text { medium-term } \\
\quad(5-10 \text { years })\end{array}$} & \multicolumn{2}{|c|}{$\begin{array}{l}\text { long-term } \\
\text { or not limited }\end{array}$} \\
\hline obligation & \multicolumn{3}{|c|}{ Informal } & \multicolumn{3}{|c|}{ contractual } \\
\hline
\end{tabular}

Fig. 1: Exemplary description of a cooperation project

Possible motives for enterprises to enter into cooperations are manifold. Most frequently, alliances or cooperations are considered by management to be an appropriate means for tapping new markets and used in this way (Balling, 1998). Moreover, opening up technology approaches and working out time and cost benefits are strong motives for the participation of SME in cooperations (Fig. 2).

Motives weighting

1. Tapping new markets 5

2. Technology approaches 4

3. Time benefits 4

4. Cost benefits 4

5. Risk diversification 3

6. Development of standards 2

7. Protection from acquisition 1

8. Retreat strategies 1

Fig. 2: Motives for entering into a cooperation

\section{CHANCES AND RISKS}

Besides a number of advantages gained from inter-company cooperations, there are also risks. One should mention here the access barrier - the naturally occurring 
and "healthy" mutual distrust between enterprises - as obstacles to an entry into a cooperation. Examples of these fears include:

- acquisition by potential competitors;

- draining of specific know-how;

- inefficient work in the cooperation (loss of time due to useless communication and search of partners) (Dathe, 1998).

These risks are opposed to enormous chances. Thus a cooperation of different SME obtains through focusing their competencies the possibility of tapping markets that would be out of reach for the individual enterprises in most cases. Tapping a market from within the cooperation is often possible for the enterprises involved at low expense.

In principle, the elaboration of a conception of cooperation alliances should focus on a demand-oriented initiation. This ensures that the cooperation project will have a high degree of market reference.

\section{COOPERATION MANAGEMENT}

\subsection{Phase conception of cooperation management}

Previous systems intended for supporting cooperation projects (especially for SME) have almost exclusively been developed for finding or initiating cooperations (Eli, 1997). However, they largely neglect the management of the cooperation course in the implementation phase. To securely reach the goal of the cooperation alliance requires not only choosing the right partner, but rather a coordinated procedure (goal harmonization and determination) and cooperation process controlling.

The basic course in the development of a virtual alliance, based on a phase conception where can be distinguished the individual phases

- Orientation, initiation;

- Search for partners, partner selection;

- Cooperation design;

- Implementation and organizational design;

- Development and termination

A cooperation alliance is initiated, based on an enterprise-specific analysis of potentials and the evaluation of the relative resource strength of individual enterprises. On the one hand, the agents involved check the profile of requirements of the intended cooperation object. On the other hand, demands on the overall business situation of potential cooperation partners are described to be able to evaluate their cooperation suitability. The evaluation using business metrics is used as a protective measure serving to reduce as far as possible the risk of a failure of the cooperation project due to a partner's insolvency. This is compellingly necessary as the success of the cooperation project is defined as the sum of all individual enterprises' results and as the jointly produced tender has to be presented jointly in the market. 
Within the initiation and orientation phase, strategy approaches are subsequently developed for the detailed determination of a suitable and promising cooperation object. Physical properties are determined, which comprise the value-creation stages to be included in case of a cooperation alongside the value creation chain, or the specification of product characteristics in case of a product cooperation

\subsection{Confidence - basis of cooperation}

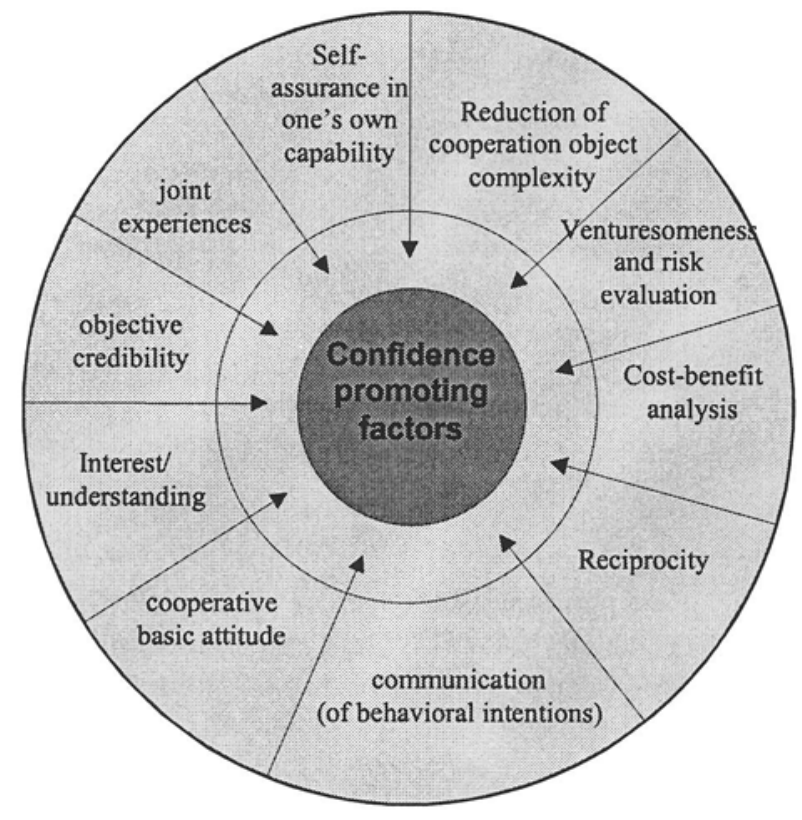

Fig. 3: Factors for the creation of confidence

The definition of the cooperation object is followed by the final formation of the cooperation alliance. One central activity in this is the selection and evaluation of potential cooperation partners.As a rule, there is a specified profile of technical/technological requirements elaborated during the initiation phase for evaluating potential cooperation partners; this cannot, however, be considered a sufficient criterion for successfully structuring the cooperation project. It rather turned out recently that, similarly to the in-house design of innovation projects (Kühnle, 1995), humans as the main agents play a decisive role also for success of inter-company cooperation.

It is undisputed that confidence between cooperation partners is vitally required for the efficient management of cooperation processes. In principle, the factors presented in Fig. 3 for creating confidence can be regarded as the basis for establishing cooperations between SME.

As a rule, positive experiences gained from cooperation projects induce in the parties involved the motivation to transfer the initial success into permanent sales 
increases. However, this depends greatly on the cooperation object. In case of cooperations alongside the value creation chain, knowledge concerning the type of cooperation project structure, in combination with experienced effects and impressions of the operation of cooperation partners, can be processed and stored in a latent knowledge base. Contrary to that, this is not easily possible in case of mere product new developments, which exhibit highly variable initial conditions from project to another.

\subsection{Management of implementation - warrant of long-term cooperation success}

It can be stated specially for cooperations the cooperation object of which exhibits a simple structure that the basis of confidence is at least consolidated with increasing cooperation intensity and with the growing number of implemented projects.

As far as the design of a cooperation is concerned, phases of the cooperation process can be viewed level by level, according to Kühnle (1995). This is based on theme-specific focusing on design aspects within the six-level view of the Fractal Factory, which has already multiply stood the test as the basis for the Fractal Factory conception. On the other hand, both cooperation management and the type of the virtual alliance can be regarded as a further development of existing, successful decentralization conceptions within production systems (Fig. 4). Thus, Schuh/Millarg/Goransson (1998) describe the virtual factory as an impress of cooperation and as a logical consequence of the conception of fractal interorganizational structures on the level of inter-company cooperation (Schuh/Millarg/Görensen, 1998). 


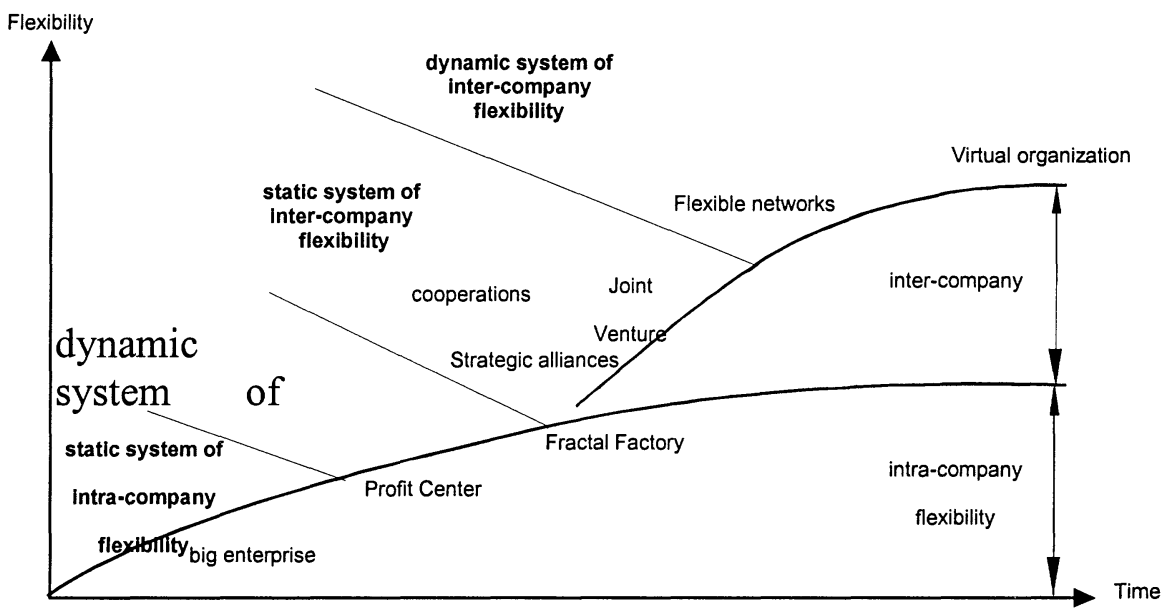

Fig. 4: Developmental stages of intra- and inter-organizational flexibility (following Schuh/Millarg/Görensen, 1998)

Compared with conventional development projects, implementing a cooperation for developing products makes high demands on managing the process. The management system presented below makes it possible for the cooperation management to recognize just those critical states during the cooperation process and to preventively interfere, if need be.

Step 1: $\quad$ Systematization of the features describing the cooperation process

Step 2: $\quad$ Intensification of characteristic features into indicators or an indicator system

Step 3: Integration of this indicator system into the management system Step 4: $\quad$ Application

\section{PROSPECTS}

More recent approaches such that by Fleischer (Fleischer, 1997) claim a cooperation-specific design of the management of cooperation alliances. They focus their considerations concerning conflict management on conflict recognition/analysis as well as subsequent mastering conflicts. However, no systematized hints or orientation values for designing or handling a system for registering or using features for describing cooperation processes have been stated so far. Thus it should be the aim of further research work to develop a tool that, beyond the establishment of cooperations, attends, evaluates and corrects them. The Fraunhofer IFF addresses this task with ist project KORAMA - cooperation manager - in the framework of which a tool is being developed for the successful guidance of cooperation alliances functioning over a long term; the tool is based on the characteristics of successfully implemented cooperations. 
There is a justified expectation that certain constellations are more promising than others and are thus destined for universally valid design recommendations. Processing the results of analysis steps leads, apart from a production engineeringoriented description model and a method for managing the cooperation based on that, to an allocation of cooperation-object properties to general action recommendations that support the cooperation to a high degree in reaching its goals.

The procedure for processing this research project comprises the following steps:

- Systematization and testing of the descriptive features

- Determination of features impresses

- Generation and intensification of cooperation process-oriented features into indicators

- Indicator system for a management system

- Exemplary application

\section{REFERENCES}

Kühnle H. (1995): Die Fraktale Fabrik - Neue Organisationsformen - der Mensch im Mittelpunkt der Fabrik, in „Kunert, W. (Hrsg.): Menschen- MaschinenMärkte die Zukunft unserer Industrie sichern“, Berlin; Heidelberg; New York

Schuh G., Millarg K., Görensen A. (1998): Virtuelle Fabrik- neue Marktchancen durch dynamische Netzwerke, München, Wien: Carl Hanser Verlag

Dathe, J. (1998): Kooperation Leitfaden für Unternehmen, Strategien, Erfahrungen und Grenzen in Europa, München, Wien: Carl Hanser Verlag

Eli, M. (1997): Der Weg der KMU in die Zukunft- Globalisierung der Märkte, Management, Innovationen; Bericht des Wirtschaftssymposium vom 9. Oktober 1997 in Chemnitz, München: Ifo-Institut für Wirtschaftsforschung

Macharzina. K., Oesterle M.-J (1997): Handbuch internationales Management: Grundlagen-Instrumente-Perspektiven, Wiesbaden: Gabler,

Balling, R. (1998): Kooperation - strategische Allianzen, Netzwerke, Joint Ventures und andere Organisationsformen zwischenbetrieblicher Zusammenarbeit in Theorie und Praxis, 2.Auflage, Frankfurt am Main [u.a.]: Lang

Fleischer, S. (1997): Strategische Kooperation - Planung - Steuerung - Kontrolle; Josef Eul Verlag, Lohmar Köln 